\title{
PREDICTION OF MEDICAL HAZARDOUS WASTE GENERATION FROM COVID-19 PATIENT HANDLING HOSPITALS
}

\section{PERKIRAAN TIMBULAN LIMBAH MEDIS BAHAN BERBAHAYA DAN BERACUN (B3) DARI RUMAH SAKIT PENANGANAN PASIEN COVID-19}

\author{
Prihartanto ${ }^{1}$ \\ ${ }^{1}$ Pusat Teknologi Reduksi Risiko Bencana, Kedeputian Bidang Teknologi Pengembangan \\ Sumberdaya Alam, Badan Pengkajian dan Penerapan Teknologi, Gedung 820, Geostech, \\ Kawasan PUSPIPTEK, Tangerang Selatan 15314 \\ e-mail: prihartanto@bppt.go.id
}

\begin{abstract}
The Covid-19 pandemic disaster has resulted in thousands peoples died and hospitalized. Handling of Covid-19 patients requires more medical equipment than normal condition, such as masks, goggles, protective clothing and so on which will increase the rate of generation of medical waste. Prediction of the total medical hazardous waste generation in Indonesia can be calculated using the prediction model of the total number of Covid-19 cases and the average generation of medical waste for each one patient. In this study, the capacity of a hazardous waste incinerator in Indonesia is also calculated to determine the time needed for waste processing. Besides, standar procedures for handling medical hazardous waste from source to final disposal site are also needed.
\end{abstract}

Keywords: covid-19, hazardous waste, medical, infectious, incinerator.

\begin{abstract}
Abstrak
Bencana pandemik Covid-19 telah mengakibatkan ribuan orang meninggal dan dirawat di rumah sakit. Penanganan pasien Covid-19 membutuhkan perlengkapan medis yang lebih banyak daripada kondisi normal, seperti masker, kacamata, pakaian pelindung dan sebagainya yang akan meningkatkan laju timbulan limbah medis. Prediksi timbulan total limbah medis bahan berbahaya dan beracun (B3) Covid-19 di Indonesia dapat dihitung menggunakan model prediksi jumlah total kasus Covid-19 dan timbulan rata-rata limbah medis untuk setiap satu orang pasien yang dirawat. Dalam studi ini dihitung juga kapasitas insinerator limbah B3 di Indonesia untuk menghitung waktu pengolahan yang dibutuhkan. Di samping itu dibutuhkan pula prosedur standar untuk penanganan limbah medis B3 dari sumber hingga tempat pembuangan akhir.
\end{abstract}

Kata kunci: covid-19, limbah B3, medis, menular, insinerator.

\section{PENDAHULUAN}

Terjadinya bencana non-alam pandemik Covid-19 yang dimulai dari Kota Wuhan, Provinsi Hubei, China pada akhir tahun 2019 telah mengakibatkan terjadi penularan lintas negara yang mengakibatkan banyak korban jiwa di seluruh dunia hingga awal tahun 2020. Pada tanggal 11 Maret 2020, World Health Organization (WHO) telah menyatakan bahwa Covid-19 sebagai global pandemic yang kemudian diikuti dengan penetapan bencana non alam penyebaran Corona Virus Disease
2019 (Covid-19) sebagai bencana nasional berdasarkan Keputusan Presiden Republik Indonesia nomor 12 tahun 2020 (Setneg RI, 2020). Dalam Undang-Undang No. 24 Tahun 2007 tentang Penanggulangan Bencana didefinisikan bahwa bencana non alam adalah bencana yang diakibatkan oleh peristiwa atau rangkaian peristiwa non alam yang antara lain berupa gagal teknologi, gagal modernisasi, epidemi, dan wabah penyakit (Kemenkumham RI, 2007). Dengan diberlakukannya keputusan presiden tersebut, maka seluruh sumberdaya dikerahkan pada penanganan para korban di 
rumah sakit khusus penanganan Covid-19.

Semua individu yang berada di rumah sakit berisiko untuk terpapar limbah Bahan Berbahaya dan Beracun (B3), tidak saja terhadap pasien namun juga individu yang bekerja di rumah sakit seperti tenaga medis, administrasi dan pendukung. Akibat pengelolaan yang kurang hati-hati, petugas yang berada di tempat perawatan kesehatan yang menghasilkan limbah B3 maupun yang berada di luar sumber ini namun bertugas untuk menangani limbah tersebut berisiko terpapar limbah B3 (Narayana et al., 2014). Pembuangan limbah ini secara sembarangan oleh lembaga layanan kesehatan dan lembaga penelitian dapat berkontribusi pada penyebaran penyakit serius terutama pada saat terjadi wabah pandemik. Karena pentingnya penanganan limbah medis rumah sakit selama terjadinya pandemik ini, maka beberapa peneliti memfokuskan studinya kepada pengelolaan limbah medis rumah sakit yang dikaji dari berbagai sudut pandang.

Beberapa penelitian menjelaskan definisi pandemik dan dampak negatif pada kesehatan, ekonomi, keamanan sosial dan global yang diakibatkan oleh pandemik dan wabah penyakit (Qiu et al, 2017). Penelitian lain terkait kepada risiko paparan, tindakan pengaturan pengelolaan limbah medis, prosedur pengelolaan limbah medis, dan teknik kontrol (Shareefdeen, 2012), tinjauan tentang pengelolaan limbah rumah sakit di negaranegara berkembang (Ali, 2017) dan limbah medis di China (Yong, 2009). Meskipun penelitian tersebut berkaitan dengan penanganan pandemik dan pengelolaan limbahnya, namun belum berkaitan dengan Covid-19.

Hingga bulan Maret 2020 ini belum banyak studi yang berkaitan dengan Covid-19. Beberapa penelitian yang telah dilakukan diantaranya tentang karakteristik struktur dan mekanisme infeksi serta pengembangan pendekatan-pendekatan dalam pengobatan Covid-19 (Nadeem, 2020), beberapa lainnya meneliti tentang sumber asal, transmisi dan terapi klinis (Guo, 2020). Namun seiring dengan meningkatnya kuantitas limbah medis selama penanganan Covid-19, maka beberapa peneliti menfokuskan pada studi pengelolaan limbah medis infeksius. Studi yang menuliskan tentang pengelolaan limbah selama pandemik Covid-19 diantaranya mengenai tantangan pengelolaan sampah reguler selama terjadi pandemik Covid19 (Ramusch, 2020) dan desain manajemen limbah yang efektif selama epidemi Covid-19 (Yu, 2020). Beberapa lembaga international juga membuat panduan tentang pengelolaan limbah medis (ADB, 2020), penjelasan teknis pengelolaan air, sanitasi, higiene dan limbah (WHO, 2020) untuk Covid-19. Hingga bulan April 2020 di Indonesia masih belum ada penelitian tentang pengelolaan limbah medis B3 yang kuantitasnya meningkat secara signifikan di beberapa rumah sakit yang menangani pasien Covid-19.

Terjadinya pandemik Covid-19 di Indonesia menuntut upaya yang masif dalam pencegahan dan penularan penyakit infeksi tersebut dengan berbagai macam cara. Prinsip pencegahan penularan penyakit infeksi Covid-19 adalah melalui pemutusan rantai host/penjamu/inang. Salah satu upaya yang dapat dilakukan adalah dengan pengelolaan limbah medis rumah sakit yang dikategorikan sebagai limbah Bahan Berbahaya dan Beracun (B3) dengan baik dan benar sesuai dengan Permen LHK No. P.56/Menlhk-Setjen/2015 tentang Tata Cara dan Persyaratan Teknis Pengelolaan Limbah B3 dari Fasilitas Pelayanan Kesehatan (Kemenkumham RI, 2016).

Penanganan pasien Covid-19 yang sangat meningkat di Indonesia membutuhkan perlengkapan medis yang lebih banyak seperti masker, kacamata, pakaian pelindung dan sebagainya. Hal ini akan mengakibatkan peningkatan timbulan limbah medis B3 rumah sakit secara signifikan, sehingga membutuhkan juga peningkatan kapasitas pengelolaan limbahnya dari aspek kuantitas dan kualitasnya. Dengan demikian diharapkan tidak terjadi penularan kembali dari limbah medis B3 rumah sakit yang digunakan. Adapun tujuan dari penelitian ini adalah memberikan gambaran tentang prediksi awal timbulan limbah medis rumah sakit selama masa penanganan pandemik Covid-19, kapasitas pengolahan, dan prosedur penanganannya.

\section{BAHAN DAN METODE}

\subsection{Bahan}

Dalam penelitian ini, bahan yang digunakan berupa data dan artikel-artikel yang diperoleh dari buku, laporan ataupun jurnal ilmiah terkait studi yang diterbitkan secara nasional maupun internasional. Hasil dari studi literatur terhadap artikel-artikel tersebut digunakan sebagai referensi, sedangkan data dan model yang diperoleh digunakan sebagai dasar perhitungan prediksi timbulan limbah medis B3 Covid-19.

\subsection{Metode}

Pada tahapan awal penelitian dilaksanakan dengan melakukan studi pustaka melalui 
penelusuran literatur berupa buku, laporan, maupun artikel ilmiah yang digunakan sebagai referensi. Berdasarkan studi pustaka tersebut dilakukan indentifikasi data dan model-model prediksi jumlah total kumulatif kasus Covid-19 hingga akhir bulan April 2020. Hasil prediksi jumlah total kumulatif kasus Covid-19 akan digunakan sebagai dasar perhitungan prediksi timbulan total limbah medis B3 Covid-19 dengan beberapa skenario intervensi dalam penanganan Covid-19 sesuai dengan model yang dikembangkan oleh Fakultas Kesehatan Masyarakat, Univeritas Indonesia/FKM-UI (Damarjati, 2020). Dengan mempertimbangkan kapasitas maksimum pengolahan limbah B3 menggunakan insinerator yang tersedia di Indonesia, maka dapat dihitung kebutuhan waktu operasional efektif insinerator-insinerator tersebut untuk setiap skenario-skenario intervensi yang digunakan dalam model.

\section{PEMBAHASAN}

\subsection{Timbulan Limbah Medis B3 Rumah Sakit Sebelum Pandemik Covid-19}

Menurut survei dari Persatuan Rumah Sakit Seluruh Indonesia (Persi) pada bulan September 2018 memperlihatkan bahwa jumlah limbah padat medis dari seluruh rumah sakit yang menjadi responden (94 responden dari berbagai kelas RS) adalah 11.745 - 12.026 kg/ hari. Sedangkan menurut Kemenkes pada bulan Agustus 2018 jumlah timbulan limbah B3 dari Fasilitas Pelayanan Kesehatan (Fasyankes) menurut hasil analisis data rumah sakit seluruh provinsi di Indonesia pada tahun 2018 adalah 294,66 ton/hari, yang dihasilkan dari 264.474 tempat tidur dari 2.867 rumah sakit. Hal ini setara dengan rata-rata timbulan limbah B3 sebesar 1,1 kg/tempat tidur/hari (Dit. PKPLB3, 2018). Timbulan sampah yang dihasilkan oleh Rumah Sakit Umum Daerah (RSUD) Dr. Soetomo Surabaya pada Tahun 2017 sebesar 1200 - 1500 kg/hari (Purwanti, 2018).

\subsection{Timbulan Limbah Medis B3 pada Saat Pandemik Covid-19}

Terjadinya pandemik Covid-19 pada akhir tahun 2019 hingga tahun 2020 mengakibatkan peningkatan yang signifikan terhadap timbulan sampah medis di rumah sakit di seluruh dunia. Saat puncak wabah, rumah sakit di Wuhan menghasilkan limbah medis enam kali lebih banyak dibandingkan sebelum krisis itu terjadi, yaitu dalam sehari menghasilkan limbah medis hingga 240 metrik ton dan membangun pabrik limbah medis baru dan menyebarkan 46 fasilitas pengolahan limbah secara mobile (Pradana, 2020).

Studi Persi berdasarkan kasus Covid-19 di China menunjukkan bahwa kapasitas pembuangan limbah medis semula 4.902,8 ton/hari kemudian meningkat sebesar 1.164 ton/hari menjadi 6.066,8 ton/hari (Nugraha, 2020) dengan timbulan limbah medis 14,3 kg/hari (Astuti, 2020). Penanganan penyakit-penyakit infeksi membutuhkan perlengkapan medis yang lebih banyak seperti masker, kacamata, pakaian pelindung dan sebagainya yang akan meningkatkan laju timbulan limbah medis. Asumsi timbulan limbah medis dari pasien Covid-19 sebesar 2,5 kg/tempat tidur lebih tinggi daripada timbulan limbah medis harian sebesar 0,6 kg/tempat tidur pada tahun 2018 (Yu, 2020). Pada Januari 2020, jumlah timbulan limbah B3 medis di RSPI Sulianti Saroso adalah sebesar $2.750 \mathrm{~kg}$, meningkat menjadi $4.500 \mathrm{~kg}$ pada bulan Maret 2020, seiring dengan peningkatan pasien Covid-19 yang dirawat di rumah sakit tersebut (Deni, 2020). Dirjen PSLB3 KLHK menyebut berdasarkan informasi dari Persatuan Rumah Sakit Indonesia (Persi), perkiraan penambahan volume timbulan limbah sekitar 30\%. (Mapapa, 2020).

Melihat adanya potensi bahaya dari limbah medis penanganan Covid-19, Kementerian Lingkungan Hidup dan Kehutanan (KLHL) mengeluarkan pedoman pengelolaan limbah tersebut. Pedoman itu termuat dalam Surat Edaran No. SE.2/MENLHK/PSLB3/3/2020 tentang Pengelolaan Limbah Infeksius (Limbah B3) dan Sampah Rumah Tangga dari Penanganan Corona Virus Disease (Covid-19) tertanggal 24 Maret 2020 (KLHK RI, 2020). Beberapa hal penting adalah sebagai berikut: alat dan sampel laboratorium yang telah digunakan merupakan Limbah B3 berupa limbah infeksius (A337-1), sehingga perlu dikelola sebagai Limbah B3 sekaligus untuk mengendalikan, mencegah dan memutus penularan Covid-19 serta menghindari terjadinya penumpukan limbah yang ditimbulkan dari penanganan Covid-19.

\subsection{Prediksi Jumlah Penderita Covid-19 yang Dirawat di Rumah Sakit}

Untuk memperkirakan jumlah timbulan limbah medis Covid-19 perlu diketahui jumlah puncak pasien positif penderita Covid19 dan kapasitas rumah sakit yang tersedia. Hingga tanggal 27 April 2020, jumlah kumulatif penderita Covid-19 terkonfirmasi positif sebesar 9.096 orang dan hanya 7.180 orang atau $78,94 \%$ dari penderita yang terkonfirmasi tersebut yang dirawat (GTP Covid-19, 2020). Pemerintah 
Indonesia telah menyiapkan sebanyak 10 ribu tempat tidur di 1000 rumah sakit (RS) khusus untuk menangani pasien Covid-19 di seluruh Indonesia (GTPP Covid-19, 2020). Jumlah penderita Covid-19 yang perlu di rawat di rumah sakit akan melampaui kapasitas yang tersedia pada awal bulan Mei 2020.

Berdasarkan data BIN, diperkirakan pada bulan Juli 2020, penyebaran Covid-19 di Tanah Air akan mencapai 106.287 kasus. Menurut ITB pandemi diperkirakan berakhir saat kasus harian berada di angka 600 pasien per hari. Perhitungan tim FKM UI memprediksi, jumlah kasus di kisaran 500.000 hingga 2.500 .000 kasus dengan mempertimbangkan tingkat intervensi pemerintah. Total penderita positif Covid-19 dari perhitungan ini adalah sekitar 6.174 kasus (Aida, 2020). Berdasarkan model prediksi tersebut, apabila pemerintah menerapkan intervensi moderat, jumlah pasien yang terjangkit Covid-19 di Indonesia bisa mencapai 1,3 juta orang (Mashabi, 2020). Resume prediksi jumlah penderita Covid-19 di Indonesia diperlihatkan pada Tabel 1.

Tabel 1. Prediksi Jumlah Penderita Covid-19

\begin{tabular}{c|l|c|c}
\hline No. & \multicolumn{1}{|c|}{ Lembaga/Intitusi Riset } & Bulan Puncak & $\begin{array}{c}\text { Perkiraan Jumlah } \\
\text { Kasus Positif }\end{array}$ \\
\hline 1. & Badan Intelijen Negara (BIN) (Aida, 2020) & Juli 2020 & 106.287 \\
\hline 2. & Intitut Teknologi Bandung (Aida, 2020) & & 600 kasus/hari \\
\hline 3. & FKM UI (Aida, 2020), (Damarjati, 2020) & Juli 2020 & 106.000 \\
\hline 4. & Lembaga Eijkman (Nurita, 2020) & Awal Mei - Akhir Juni 2020 & $11.000-71.000$ \\
\hline 5. & $\begin{array}{l}\text { Tim Pakar Gugus Tugas Percepatan } \\
\text { Penanganan Covid-19 (Putri, 2020) }\end{array}$ & Awal Mei - Awal Juni & 95.000 \\
\hline
\end{tabular}

\subsection{Prediksi Timbulan Limbah Medis B3 Selama Pandemik Covid-19}

Dari Tabel 1 dapat disimpulkan bahwa seluruh model prediksi jumlah penderita Covid19 memperkirakan jumlah penderita Covid-19 jauh lebih besar daripada kapasitas pelayanan rumah sakit khusus Covid-19 di Indonesia yaitu sebesar 10.000 tempat tidur. Dengan demikian pada bulan Mei 2020 kapasitas rumah sakit akan terpenuhi seluruhnya hingga terjadi penurunan kasus Covid-19.

Berdasarkan fakta tersebut, timbulan limbah medis B3 setiap hari dapat diasumsikan berasal dari 10.000 pasien yang dirawat. Dalam kondisi normal timbulan limbah medis B3 sebesar 1,1 kg/tempat tidur/hari (Dit. PKPLB3, 2018). Dengan berdasarkan hasil studi penanganan limbah medis B3 di Wuhan China - dimana timbulan limbah medis dari pasien Covid-19 meningkat hingga sebesar 2,5 kg/tempat tidur/hari - dapat diprediksi jumlah timbulan limbah medis B3 dari rumah sakit khusus penanganan Covid-19 sebesar 25 ton/hari yang berasal dari 10.000 tempat tidur.

Apabila kapasitas maksimum rumah sakit dalam penanganan Covid-19 diabaikan, maka timbulan kumulatif total limbah medis B3 dapat diprediksikan berdasarkan model prediksi jumlah total kumulatif kasus Covid-19 di Indonesia. Dari beberapa model prediksi di Indonesia, terdapat model yang dikembangkan oleh Fakultas Kesehatan Masyarakat - Universitas Indonesia (FKM-UI) yang dapat memprediksikan jumlah kasus Covid di Indonesia berdasarkan beberapa skenario intervensi terhadap penanganan Covid19 (Damarjati, 2020). Prediksi puncak tersebut diasumsikan terjadi pada hari ke-77. Berdasarkan model tersebut dapat diprediksikan timbulan kumulatif total limbah medis B3 berdasarkan skenario yang digunakan sebagaimana diperlihatkan pada Tabel 2 .

Tabel 2. Prediksi Timbulan Kumulatif Total Limbah Medis B3 Berdasarkan Model Prediksi Jumlah Total Kumulatif Kasus Covid-19 Fakultas Kesehatan Masyarakat - Universitas Indonesia

\begin{tabular}{c|c|l|c|c|c}
\hline No. & Skenario* & Deskripsi Skenario* & $\begin{array}{c}\text { Perkiraan Jumlah } \\
\text { Total Kumulatif } \\
\text { Terjangkit Covid- } \\
19^{*} \\
\text { (Orang) }\end{array}$ & $\begin{array}{c}\text { Perkiraan } \\
\text { Timbulan Limbah } \\
\text { Medis B3 } \\
\text { Kumulatif** } \\
\text { (Ton) }\end{array}$ & $\begin{array}{c}\text { Waktu Efektif } \\
\text { Pengoperasian } \\
\text { Insinerator Limbah } \\
\text { Medis B3 Covid-19** } \\
\text { (Hari Kerja) }\end{array}$ \\
\hline 1. & $\begin{array}{l}\text { Tanpa } \\
\text { intervensi }\end{array}$ & $\begin{array}{l}\text { Tanpa jaga jarak } \\
\text { sosial, tanpa } \\
\text { pembatasan } \\
\text { kerumunan dan tanpa } \\
\text { tes masal }\end{array}$ & $+/-2.500 .000$ & $+/-6.250$ & 20 \\
\hline
\end{tabular}




\begin{tabular}{c|l|l|c|c|c}
\hline 2. & $\begin{array}{l}\text { Intervensi } \\
\text { rendah }\end{array}$ & $\begin{array}{l}\text { jaga jarak sosial } \\
\text { secara sukarela, } \\
\text { membatasi kerumunan } \\
\text { massa }\end{array}$ & $+/-1.750 .000$ & $+/-4.375$ & 14 \\
\hline 3. & $\begin{array}{l}\text { Intervensi } \\
\text { moderat } \\
\text { rendah, mengharuskan } \\
\text { jaga jarak sosial } \\
\text { (penutupan } \\
\text { sekolah/bisnis) }\end{array}$ & $+/-1.250 .000$ & $+/-3.125$ & 10 \\
\hline 4. & $\begin{array}{l}\text { Intervensi } \\
\text { tinggi }\end{array}$ & $\begin{array}{l}\text { tes masal cakupan } \\
\text { tinggi, mewajibkan } \\
\text { jaga jarak social }\end{array}$ & $+/-500.000$ & $+/-1.250$ & 4 \\
\hline
\end{tabular}

Sumber : *(Damarjati, 2020), ${ }^{*}$ Hasil analisis data

Dari Tabel 2 diperoleh hasil prediksi limbah medis B3 kumulatif berkisar antara +/- 1.250 6.250 ton yang terakumulasi dalam 77 hari.

\subsection{Kapasitas Pengolahan Limbah B3}

$\begin{array}{ccc}\text { Berdasarkan } & \text { Surat } & \text { Edaran } \begin{array}{r}\text { No. } \\ \text { SE.2/MENLHK/PSLB3/3/2020 }\end{array}\end{array}$ Pengelolaan Limbah Infeksius (Limbah B3) dan Sampah Rumah Tangga dari Penanganan Corona Virus Disease (Covid-19) (KLHK RI, 2020), limbah B3 harus ditangani secara khusus dan diolah di fasilitas insinerator limbah rumah sakit pada temperatur minimum $800^{\circ} \mathrm{C}$. Data perizinan bulan oktober 2018 dari KLHK menunjukkan kapasitas eksisting insinerator di 63 Fasyankes di Indonesia sebesar 53,12 ton/hari. Kapasitas ini akan berkembang dari 27 Fasyankes dengan kapasitas tambahan 20,16 ton/hari (Dit. PKPLB3, 2018). Sehingga kapasitas totalnya sebesar 73,28 ton/hari. Disamping kapasitas insinerator di Fasyankes, terdapat juga kapasitas pengolah limbah B3 dari 6 jasa pengolah sebesar 115,68 ton/hari dengan potensi ekspansi penambahan unit insinerator dengan kapasitas pengolahan sebesar 240 ton/hari. Dengan demikian kapasitas total insinerator limbah medis B3 eksisting yang tersedia pada tahun 2020 diperkirakan sebesar 313,28 ton per hari. Apabila seluruh kapasitas insinerator tersebut dapat dipergunakan seluruhnya untuk penanganan limbah medis B3 Covid-19, maka seluruh insinerator limbah B3 tersebut minimal dioperasikan secara efektif selama 4 hari kerja pada skenario intervensi tinggi dan mencapai 20 hari kerja pada skenario tanpa intervensi sebagaimana diperlihatkan pada Tabel 2.

\subsection{Metode Penanganan dan Pengolahan Limbah B3}

Untuk menangani limbah medis B3 Covid19 yang kuantitasnya sangat besar tersebut, perlu adanya prosedur standar penanganan dan pengolahan khusus limbah B3 Covid-19. Beberapa prosedur penanganan limbah medis B3 Covid-19 tersebut meliputi:

a. Pengurangan dan pemilahan di Fasyankes Perlu adanya prosedur untuk meningkatkan efektivitas pengelolaam dan penggunaan bahan-bahan medis B3 maupun Alat Pelindung Diri (APD) sehingga dapat mengurangi jumlah limbah yang akan ditimbulkan. Disamping itu perlu adanya prosedur pemilahan limbah medis B3 agar tidak tercampur dengan limbah-limbah non medis.

b. Pewadahan \& Penyimpanan

Prosedur pewadahan perlu menjadi perhatian penting untuk menghidari terjadi infeksi Covid-19 terhadap tenaga medis maupun paramedis, serta terhadap personil yang akan menangani limbah B3 hingga tempat pengolahan dan penimbunan. Perlu ditetapkan prosedur standar desinfeksi limbah sebelum dilakukan pewadahan dan penyimpanan. Penyimpanan sementara limbah medis B3 Covid-19 membutuhkan prosedur penanganan dan pengamanan khusus agar tidak terjadi penularan terhadap petugas.

c. Pengangkutan

Prosedur pengangkutan limbah medis B3 Covid-19 mengikuti standar prosedur teknis pengangkutan limbah B3 dan juga standar desinfeksi limbah sebelum diangkut ke tempat pengolahan.

d. Pengolahan

Pengolahan limbah medis B3 Covid-19 dilakukan sesuai dengan Surat Edaran No. SE.2/MENLHK/PSLB3/3/2020 tentang Pengelolaan Limbah Infeksius (Limbah B3) dan Sampah Rumah Tangga dari Penanganan Corona Virus Disease (Covid19) (KLHK RI.2020), yaitu menggunakan insinerator limbah B3 dengan temperatur pembakaran minimal $800^{\circ} \mathrm{C}$ dengan prosedur pengelolaan, pengoperasian dan pemantauan yang ketat. 
e. Penimbunan

Penimbunan hanya dilakukan terhadap sisa pembakaran insinerator limbah B3 kedalam lahan urug (landfill\} khusus B3 dengan prosedur pengelolaan, pengoperasian dan pemantauan yang ketat.

\section{KESIMPULAN}

Kapasitas perawatan pasien Covid-19 yang tersedia di rumah sakit di Indonesia maksimum adalah 10.000 tempat tidur di 1000 rumah sakit khusus penanganan Covid-19. Perhitungan timbulan limbah medis B3 yang dihasilkan selama terjadinya kejadian wabah pandemik Covid-19 adalah sebesar 25 ton/hari yang berasal dari 10.000 pasien Covid-19. Apabila faktor kapasitas rumah sakit khusus penanganan Covid-19 tidak diperhitungan, dengan didasarkan. model FKM-UI tentang prediksi jumlah total kumulatif kasus Covid-19, maka timbulan kumulatif limbah medis B3 Covid19 berkisar antara 1.250 ton pada skenario intervensi tinggi hingga 6.250 ton pada skenario tanpa intervensi. Dengan kapasitas total maksimum insinerator limbah medis B3 di 90 Fasyankes dan 6 perusahaan jasa pengolahan limbah B3 di Indonesia sebesar 313,28 ton/hari, dengan demikian lama pengoperasian efektif insinerator tersebut berkisar antara 4 hari kerja pada skenario intervensi tinggi dan mencapai 20 hari kerja pada skenario tanpa intervensi. Selain itu dibutuhkan prosedur standar penanganan limbah medis B3 Covid-19 yang meliputi pengurangan dan pemilahan, pewadahan dan penyimpanan, pengangkutan, pengolahan dan penimbunan.

\section{PERSANTUNAN}

Penulis mengucapkan terima kasih kepada Direktur Pusat Teknologi Reduksi Risiko Bencana (PTRRB) BPPT dan semua pihak yang telah memfasilitasi penulisan makalah ini sehingga dapat diterbitkan.

\section{DAFTAR PUSTAKA}

Aida, N.R. 2020. Prediksi Sejumlah Pakar soal Puncak Wabah Virus Corona di Indonesia". [terhubung berkala]. https://www.kompas.com/tren/read/2020/04 /03/123616065/prediksi-sejumlah-pakarsoal-puncak-wabah-virus-corona-diindonesia?page $=2$.

Ali, S.M., M.N. Chaudhry \& Y. Geng. 207. Hospital waste management in developing countries: A mini review. Waste Management \& Research. 35:1-12
10.1177/0734242X17691344.

Asian Development Bank. 2020. Managing Medical Waste Covid 19. https://www.adb.org/publications/managingmedical-waste-covid19.

Astuti, L.T.M. 2020. Webinar Covid-19 PERSI: Satu Pasien di RS Rujukan dan Darurat Hasilkan 14,3 kg Limbah Medis per Hari. [terhubung berkala]. https://www.persi.or.id/78-berita/beritapersi/1348-webinar-covid-19-persi-satupasien-di-rs-rujukan-dan-darurat-hasilkan14-3-kg-limbah-medis-per-hari.

Damarjati, D. 2020. Tim FKM UI: Tanpa Intervensi Negara, 2,5 Juta Orang RI Bisa Kena Corona. [terhubung berkala]. https://news.detik.com/berita/d-4957064/timfkm-ui-tanpa-intervensi-negara-25-jutaorang-ri-bisa-kena-corona/2.

Deni, M.C.N. 2020. Tinjauan Kebijakan Pengelolaan Limbah Medis Infeksius Penanganan Corona Virus Disease 2019 (Covid-19).

Dit. PKPLB3. 2018. Peta Jalan (Roadmap) Pengelolaan Limbah B3 dari Fasilitas Pelayanan Kesehatan (Fasyankes). Kementerian Lingkungan Hidup dan Kehutanan.

Gugus Tugas Percepatan Penanganan Covid-19. 2020. Infografis Covid-19 (27 April 2020). [terhubung berkala]. https://covid19.go.id/p/berita/infografis-covid19-27-april-2020.

Gugus Tugas Percepatan Penanganan Covid-19. 2020. [terhubung berkala]. https://covid19.go.id/p/berita/pemerintahindonesia-siapkan-10-ribu-tempat-tidur-di1000-rs-khusus-pasien-covid-19.

Guo, Y, Q. Cao, Z. Hong, Y. Tan, S. Chen, H. Jin, K. Tan, D. Wang \& Y. Yan, 2020. The origin, transmission and clinical therapies on coronavirus disease 2019 (Covid-19) outbreak - an update on the status. Military Medical Research. 7: 1-10 10.1186/s40779020-00240-0.

Mapapa, P.L. 2020. Kementerian KLHK: Limbah Medis Covid-19 Prioritas Dimusnahkan Segera. [terhubung berkala]. https://news.detik.com/berita/d4974825/kementerian-klhk-limbah-mediscovid-19-prioritas-dimusnahkan-segera.

Mashabi, S. 2020. Pakar soal Covid-19: Capai 1,3 Juta Kasus, Puncak Pandemi, hingga Gelombang Kedua. [terhubung berkala]. https://nasional.kompas.com/read/2 020/04/15/06375351/prediksi-pakar-soalcovid-19-capai-13-juta-kasus-puncakpandemi-hingga.

Kemenkumham RI. 2007. Undang-Undang 
Republik Indonesia Nomor 24 Tahun 2007 tentang Penanggulangan Bencana.

Kemenkumham RI. 2016. Peraturan Menteri Lingkungan Hidup dan Kehutanan Republik Indonesia Nomor P.56/MENLHKSetjen/2015 tentang Tata Cara dan Persyaratan Teknis Pengelolaan Limbah Bahan Berbahaya dan Beracun dari Fasilitas Pelayanan Kesehatan.

Kementrian Lingkungan Hidup dan Kehutanan RI. 2020. Surat Edaran Menteri Lingkungan Hidup dan Kehutanan.No.SE.2/MENLHK/PSLB3/PLB. 3/3/2020 Tentang Pengelolaan. Limbah Infeksiksius (Limbah B3) dan Sampah Rumah. Tangga dari penangangan Corona Virus Disease (Covid-19).

Narayana, V., S. Rudraswamy \& N. Donggali. 2014. Hazards and Public Health Impacts of Hospital Waste, Indian Journal of Applied Reseach, 4(6): 386-388.

Nurita, D. 2020. Eijkman Prediksi Puncak Covid-19 Terjadi Awal Mei-Akhir Juni. [terhubung berkala]. https://nasional.tempo.co/read/1332620/eijk man-prediksi-puncak-covid-19-terjadi-awalmei-akhir-juni.

Pradana, W.E. 2020. Bagaimana Menangani Limbah Medis Covid-19 dari RS dan Rumah ODP. [terhubung berkala]. https://kumparan.com/pandanganjogja/bagaimana-cara-menangani-limbahmedis-covid-19-dari-rs-dan-rumah-odp1t9qQp4Z2Hn/full.

Putri, T.H. 2020. Total 95 Ribu Kasus, Juni Jadi Puncak Penyebaran Covid-19 di Indonesia. [terhubung berkala]. https://kaltim.idntimes.com/news/indonesia/ teatrika/gugus-tugas-prediksi-puncak-covid19-di-indonesia-capai-95-ribu-kasusregional-kaltim.

Purwanti, A.A. 2018. Pengelolaan Limbah Padat Bahan Berbahaya dan Beracun (B3) Rumah Sakit di RSUD Soetomo Surabaya, Jurnal Kesehatan Lingkungan (UKL) Unair. 10(03): 291-298.

Quu, W., S. Rutherford, A. Mao \& C. Chu. 2017. The Pandemic and Its Impact, Health, Cultures and Society, 9: 3 - 11 10.5195/HCS.2017.221.

Ramusch, R. 2020. Covid-19 and challenges in the provision of solid waste services.

Sekretariat Negara RI. 2020. Keputusan Presiden (KEPPRES) tentang Penetapan Bencana Nonalam Penyebaran Corona Virus Disease 2019 (Cvid-19) Sebagai Bencana Nasional.

Shareefdeen, Z.M. (2012). Medical Waste Management and Control. Journal of
Environmental Protection. 3:1625-1628. 10.4236/jep.2012.312179.

World Health Organization. 2020.Water, Sanitation, Hygiene and Waste Management. [terhubung berkala]. https://www.who.int/publications-detail/watersanitation-hygiene-and-waste-managementfor-covid-19.

Yong, Z., G. Xiao, G. Wang, Z. Tao \& J. Dawei, Jiang. 2009. Medical Waste Management in China: A Case Study of Nanjing. Waste management (New York, N.Y.). 29 : 137682. 10.1016/j.wasman.2008.10.023.

Yu,H., , Sun, X., 1, Solvang, W.D., Zhao, X. 2020. Reverse Logistics Network Design for Effective Management of Medical Waste in Epidemic Outbreaks: Insights from the Corona virus Disease 2019 (Covid-19) Outbreak in Wuhan (China), International Journal of Envirinmental Research and Public Health, 17(1770): 1-25. 